\title{
A KAP Study on Food Safety and Hygiene Among Private University Students in Kedah State, Malaysia
}

\author{
Abdul Nazer Ali ${ }^{1}$, Angeline Francis William ${ }^{1}$, Sunil Kumar Prajapati ${ }^{1 *}$, Nazer Zulfikar Ahmed ${ }^{2}$ \\ 1AIMST University, Jalan Bedong-Semeling, 08100 Bedong, Kedah, Malaysia; abdul.nazerali16@gmail.com, \\ angefran@yahoo.com, clinical.sunil@gmail.com \\ ${ }^{2}$ Cognizant Technology Solutions India Private Limited, Hyderabad, India; n.zulfik@gmail.com
}

\section{Abstract}

Objective: To assess the student's Knowledge, Attitude and Perception (KAP) towards food safety and hygiene in a private University campus catering food to students. Method: This is a cross sectional study, using pre validated questionnaire containing three sections and a total of 36 items. The survey was conducted in a private (AIMST) University campus involving students of various disciplines through self-administered survey forms. The completed questionnaires were analyzed using SPSS version 23 and statistical significance was assessed using Chi-square test. The correlations of KAP score towards the independent demographic variables and the presence of predictor variables using linear regression was done. Result: Among 869 respondents, the KAP scores based on socio-demographic variable were found to be significant in relation to the independent variables. The median KAP score was 92(11), with a minimum (48) and maximum (104). In the gender category, more than half of the respondents were female, among the course of study more than half had an overall positive KAP score $(90 \%)$ regarding food safety and hygiene. Overall, all of the courses had attained a good KAP score when compared to moderate and poor score. Among the type of diet category, an overall good KAP score (90\%) was observed with non-vegetarian, showed positive scoring compared to vegetarians. The Spearman's correlation of knowledge, attitude and perception scores were found to be positively correlated $[\mathrm{r}(869)$ $=.902, p<.001]$ with KAP scores. Conclusion: Majority of respondents showed good knowledge, attitude, and perception towards all domains and showed significant results and correlation. Continuous education is necessary to increase the awareness among young adults in the near future; they will be the ones directly handling food and play an important role to help maintain a hygienic and clean environment.

Keywords: Attitude, Food Safety and Hygiene, Knowledge, Perception, University Students

\section{Introduction}

Food hygiene is the condition and measure necessary to ensure the safety of food from production to consumption. Food can become contaminated at any point during harvesting, processing, storage, distribution, transportation and preparation. Lack of adequate food hygiene practice can lead to food borne diseases and death of the consumer. The World Health Organization
(WHO) assists in promoting safe food handling through systematic disease prevention and education programs directed to food handlers, including the consumers ${ }^{1}$.

A number of studies have reported that frequent food handling problems among consumer groups is mainly between 18-29 years of age with an education above high school level ${ }^{1}$ compared to other individuals, due to poor food handling practices. Though these individuals were 
not considered to show behaviours of risky food handling practices, as they are not the high risk population compared to pregnant women, children and elderly persons, the importance of food handling behaviours, practices, attitude and knowledge will be very important, considering their future roles as caretakers of the public, caregivers for their families ${ }^{2}$. It is known that education for consumers is one of the main interventions to increase the knowledge. However, based on marketing experts from United States, educational programs directed to "all" will only meet the needs of $\mathrm{few}^{3-5}$.

Based on the problem, it is important to evaluate the student's level of knowledge, which will determine their perception and subsequently transform into their behaviour. Majority of food handlers do not have a proper background education on regulations of food safety and hygiene, but still have been brought into the industry as food handlers. Knowledge, attitude and perception on food safety and hygiene are very important considering their future roles in life as an individual and also being part of family members. Despite efforts taken by the $\mathrm{MoH}$, Malaysia, for schools by checking the premises and also training the food handlers to practice safe food handling, outbreaks continue to occur ${ }^{6}$. Hence, through this, we can infer that, not only food handlers are to be educated but students and public in general should be educated on the knowledge of food safety and hygiene. It is also important to identify the factors associated with knowledge among this study population. This study outcome may pave necessary intervention opportunities for the catering management to consider and enhance on food safety and hygiene and plan appropriate strategies to reduce prevalence of food borne diseases.

\subsection{Outcome Measures}

The main outcome measure of this study was to assess the student's $\mathrm{KAP}^{7}$ towards food safety and hygiene in a private university campus catering food to students.

\section{Materials and Methods}

\subsection{Study Design and Target Population}

A cross sectional study was done among a private university students belonging to various study backgrounds in Kedah State, Malaysia. The study was done between March and
May, 2018. The studies inclusion criteria included: both male and female students of various faculties willing to participate and signed the informed consent form. Those not willing, incomplete survey forms, those who did not sign the informed consent form and involved in pilot study were excluded.

\subsection{Sample Size Calculation}

Total number of students in the university according to university portal (UniRankPortal) was utilized as total student's population from which the sample size was calculated using an automated Raosoft sample size calculator $^{8}$. The estimated sample size was calculated at $95 \% \mathrm{CI}, 5 \%$ margin of error with $50 \%$ response distribution and the sample size required was 385 . A $10 \%$ margin for drop-outs was added and rounded off to get a final sample of 420 .

\subsection{Development of Study Tool (Questionnaire)}

The questionnaire consists of three sections testing knowledge, attitude and perception about food safety and hygiene excluding socio-demographic profile of participants. The questions for the study were adapted from various literatures and official websites like CDC, $\mathrm{WHO}, \mathrm{MoH}$ etc. The questions / statements were modified to suit the objectives of the study. Questions pertaining to knowledge included dining place cleanliness, personal hygiene, food processing, food contamination, its identification, signs and symptoms of food poisoning etc ${ }^{9-11}$. Statements pertaining to attitude included hand washing techniques/habits, disposal of food waste, maintenance of rubbish bin, stray/pet animals in dining areas etc ${ }^{12,13}$. Perception based statements include food services, responsibilities of food handlers, sanitation of cooking and dining area, personal hygiene of food handlers, disposal of waste food, tidiness of food service/dining area etc ${ }^{13,14}$. Content and face validation of questionnaire was done by physicians, expert in community health. Reliability was also tested using pilot study and Cronbach's alpha coefficient was found to be $.70^{15}$.

\subsection{Ethical Consideration}

A research proposal along with the study instruments and informed consent form were submitted to the Institutional Review Board (IRB), AIMST University 
Human Ethical Committee for ethical clearance. Informed consent form was obtained from respondents before the survey questionnaire were distributed. Participation in the study was completely voluntary and was allowed to withdraw from the study at any point of time.

\subsection{Statistical Analysis of Data}

The survey data analysed using Statistical Package for Social Sciences 'SPSS version - 23' for windows. The categorical variables were illustrated using descriptive statistics for frequency, percentage, median and IQR and p-value computed using Pearson's Chi square test. A p value $<.05$ was considered significant. Inferential statistics were performed using Spearman's correlation.

\section{Results}

The overall response rate of the respondents was $79 \%$ $(\mathrm{N}=869 / 1100)$, the drop-outs were mainly due to incomplete questionnaires.

\subsection{Socio-Demographic Profile}

The overall socio-demographic profile are shown in Table 1.

Table 1. Socio-demographic profile of respondents $(\mathrm{N}=896)$

\begin{tabular}{lcc}
\hline \multicolumn{1}{c}{ Variables } & N & Percentage \\
\hline Age & & \\
\hline $18-20$ & 329 & 38 \\
$21-23$ & 487 & 56 \\
$24-26$ & 47 & 5 \\
$>26$ & 6 & 1 \\
\hline Gender & & \\
\hline Male & 219 & 25 \\
Female & 650 & 75 \\
\hline Race & & \\
\hline Malay & 34 & 4 \\
Indian & 176 & 20
\end{tabular}

\begin{tabular}{lcc}
\hline \multicolumn{1}{c}{ Variables } & N & Percentage \\
\hline Chinese & 648 & 75 \\
Others & 11 & 1 \\
\hline Education & & \\
\hline Foundation \& diploma & 203 & 23 \\
Degree & 666 & 77 \\
\hline Faculty & & \\
\hline Foundation \& diploma & 75 & 9 \\
Medicine & 131 & 15 \\
Dentistry & 170 & 20 \\
Pharmacy & 215 & 24 \\
Physiotherapy & 41 & 5 \\
Business & 167 & 19 \\
Biotechnology & 70 & 8 \\
\hline Years of Study & & \\
\hline Year 1 & 337 & 39 \\
Year 2 & 164 & 19 \\
Year 3 & 227 & 26 \\
Year 4 & 117 & 13 \\
Year 5 & 24 & 36 \\
\hline Type of Diet & & \\
\hline Vegetarian & 34 & 48 \\
Non vegetarian & 681 & \\
\hline Location & & \\
\hline Rural & & \\
Urban & & \\
\hline Frequency and percentages are distribution of the study subjects & \\
\hline & & \\
\hline
\end{tabular}

Frequency and percentages are distribution of the study subjects with regard to socio demographic characteristics.

\subsection{Responses Towards Knowledge Based Items}

The knowledge section was made up of 14 questions, with ' 1 ' score given for each correct answer and zero score for the incorrect answer. The total knowledge score is derived by summing up all the 14 knowledge-based items.

Among the responses, $\mathrm{K} 1, \mathrm{~K} 2$ and $\mathrm{K} 9$, were found to acquire the maximum percentage of correct responses (95\%, 94\% and 93\% respectively). However, the minimum percentages of correct responses were, K4, K5 and K11 with 50\%, 41\% and 58\% respectively (Table 2). 
Table 2. Proportion of correct responses towards knowledge based Items ( $N=869)$

\begin{tabular}{|c|c|c|c|c|c|c|}
\hline \multirow{2}{*}{ No. } & \multirow{2}{*}{ Knowledge Items } & \multicolumn{2}{|c|}{ Correct } & \multicolumn{2}{|c|}{ Incorrect } & \multirow{2}{*}{${ }^{*} p$-value } \\
\hline & & $\mathbf{N}$ & (\%) & $\mathbf{N}$ & $(\%)$ & \\
\hline 1. & Definition of food safety. & 825 & (95) & 44 & (5) & $<.001$ \\
\hline 2. & Causes of food borne diseases. & 813 & (94) & 56 & (6) & $<.001$ \\
\hline 3. & Statistics of food borne diseases. & 684 & (79) & 185 & $(21)$ & $<.001$ \\
\hline 4. & $\begin{array}{l}\text { Common cause of food borne } \\
\text { disease. }\end{array}$ & 434 & $(50)$ & 435 & $(50)$ & 0.973 \\
\hline 5. & $\begin{array}{l}\text { Long term effect of food borne } \\
\text { disease. }\end{array}$ & 509 & $(59)$ & 360 & $(41)$ & $<.001$ \\
\hline 6. & Risk factor for food borne diseases. & 697 & $(80)$ & 172 & $(20)$ & $<.001$ \\
\hline 7. & Detection of safe food. & 746 & (89) & 123 & (14) & $<.001$ \\
\hline 8. & Methods of cross contamination. & 764 & (88) & 105 & $(12)$ & $<.001$ \\
\hline 9. & Symptoms of food borne diseases. & 810 & (93) & 59 & (7) & $<.001$ \\
\hline 10. & $\begin{array}{l}\text { Awareness program on food safety } \\
\text { and hygiene. }\end{array}$ & 496 & (57) & 373 & $(43)$ & $<.001$ \\
\hline 11. & Storage methods of food. & 367 & $(42)$ & 502 & $(58)$ & $<.001$ \\
\hline 12. & Cause of Leptospirosis diseases. & 530 & (61) & 339 & (39) & $<.001$ \\
\hline 13. & Symptoms of food poisoning. & 807 & (93) & 62 & (7) & $<.001$ \\
\hline 14. & $\begin{array}{l}\text { Causative organism for food borne } \\
\text { disease. }\end{array}$ & 528 & $(61)$ & 341 & (39) & $<.001$ \\
\hline
\end{tabular}

${ }^{*}$ Chi square test: $p<.05$ is statistically significant

\subsection{Responses towards Attitude Based Statements}

The attitude section was made up of 10 questions, with scores of ' 3 to 1' (three point Likert scale) for positive to negative agreement for each statement. The total attitude score-is acquired by the sum of 10 attitude related items ranging from 10 to 30 . It was observed that statements A1, A3 and A10 scored the best agreement with 94\%, 93\% and $91 \%$ whereas, statement A5 showed minimum agreement with $41 \%$ (Table 3 ).

Table 3. Responses towards attitude based statements $(\mathrm{N}=869)$

\begin{tabular}{|c|c|c|c|c|c|}
\hline No. & Attitude based Statements & Disagree N (\%) & Neutral N (\%) & Agree N (\%) & *P Value \\
\hline 1. & $\begin{array}{l}\text { Before eating, one should wash their } \\
\text { hands. }\end{array}$ & $\begin{array}{c}9 \\
(1)\end{array}$ & $\begin{array}{l}40 \\
(5)\end{array}$ & $\begin{array}{l}820 \\
(94)\end{array}$ & $<.001$ \\
\hline 2. & $\begin{array}{l}\text { Students should clean their crumbs/ } \\
\text { spilled food once they have eaten. }\end{array}$ & $\begin{array}{l}20 \\
(2)\end{array}$ & $\begin{array}{l}130 \\
(15)\end{array}$ & $\begin{array}{l}719 \\
(83)\end{array}$ & $<.001$ \\
\hline 3. & $\begin{array}{l}\text { Rubbish should be thrown into the } \\
\text { rubbish bin and closed with the lid. }\end{array}$ & $\begin{array}{c}9 \\
(1)\end{array}$ & $\begin{array}{l}54 \\
(6)\end{array}$ & $\begin{array}{l}806 \\
(93)\end{array}$ & $<.001$ \\
\hline 4. & $\begin{array}{l}\text { Students feeding food to the stray } \\
\text { animals cause the animals and } \\
\text { insects to continuously enter the } \\
\text { dining area. }\end{array}$ & $\begin{array}{l}77 \\
(9)\end{array}$ & $\begin{array}{l}231 \\
(26)\end{array}$ & $\begin{array}{l}561 \\
(65)\end{array}$ & $<.001$ \\
\hline 5. & $\begin{array}{l}\text { Students do not wash their hands } \\
\text { before eating is because the wash } \\
\text { basin is not kept clean. }\end{array}$ & $\begin{array}{l}191 \\
(22)\end{array}$ & $\begin{array}{l}323 \\
(37)\end{array}$ & $\begin{array}{l}355 \\
(41)\end{array}$ & $<.001$ \\
\hline 6. & $\begin{array}{l}\text { Students should complain to the } \\
\text { person in charge if any insects were } \\
\text { to be found on their meal. }\end{array}$ & $\begin{array}{l}11 \\
(1)\end{array}$ & $\begin{array}{l}73 \\
(9)\end{array}$ & $\begin{array}{l}785 \\
(90)\end{array}$ & $<.001$ \\
\hline
\end{tabular}




\begin{tabular}{|c|c|c|c|c|c|}
\hline No. & Attitude based Statements & Disagree N (\%) & Neutral N (\%) & Agree N (\%) & *PValue \\
\hline 7. & $\begin{array}{l}\text { Students with unclean/uncut finger } \\
\text { nails can cause contamination to } \\
\text { their food. }\end{array}$ & $\begin{array}{l}27 \\
\text { (3) }\end{array}$ & $\begin{array}{l}146 \\
(17)\end{array}$ & $\begin{array}{l}696 \\
(80)\end{array}$ & $<.001$ \\
\hline 8. & $\begin{array}{l}\text { Students should help to improve } \\
\text { the quality of food by providing } \\
\text { constructive feedback to the } \\
\text { management. }\end{array}$ & $\begin{array}{l}13 \\
(2)\end{array}$ & $\begin{array}{l}117 \\
(13)\end{array}$ & $\begin{array}{l}739 \\
(85)\end{array}$ & $<.001$ \\
\hline 9. & $\begin{array}{l}\text { Once done with their meal, students } \\
\text { should not leave their bowls on the } \\
\text { table. }\end{array}$ & $\begin{array}{l}22 \\
\text { (3) }\end{array}$ & $\begin{array}{l}77 \\
\text { (8) }\end{array}$ & $\begin{array}{l}770 \\
(89)\end{array}$ & $<.001$ \\
\hline 10. & $\begin{array}{l}\text { Students should cover their mouth } \\
\text { with a napkin when they sneeze or } \\
\text { cough, to avoid cross contamination. }\end{array}$ & $\begin{array}{l}10 \\
(1)\end{array}$ & $\begin{array}{l}65 \\
(8)\end{array}$ & $\begin{array}{l}794 \\
(91)\end{array}$ & $<.001$ \\
\hline
\end{tabular}

${ }^{*}$ Chi square test: $p<.05$ is statistically significant

\subsection{Responses towards Perception Based Statements}

The perception section was made up of 12 statements with scores of ' 5 to 1' (five point Likert scale) for positive to negative agreement for each statement. The total attitude score-is acquired by the sum of 10 attitude related items. It was observed the statements with best agreement were $\mathrm{P} 2=91 \%, \mathrm{P} 4=92 \%, \mathrm{P} 5=92 \%, \mathrm{P} 6=$ $91 \%, \mathrm{P} 7=92 \%, \mathrm{P} 9=91 \%$ respectively whereas, $\mathrm{P} 8$ observed only $53 \%$ agreement (Table 4 ).

Table 4. Responses towards the perception based Statements $(\mathrm{N}=869)$

\begin{tabular}{|c|c|c|c|c|c|c|c|}
\hline P. No. & Perception based statement & $\begin{array}{l}\text { SD } \\
\mathrm{N}(\%)\end{array}$ & $\begin{array}{c} \\
N(\%)\end{array}$ & $\begin{array}{c}\mathrm{N} \\
\mathrm{N}(\%)\end{array}$ & $\begin{array}{c}\text { A } \\
\text { N (\%) }\end{array}$ & $\begin{array}{c}\text { SA } \\
\text { N (\%) }\end{array}$ & ${ }^{*} p$ value \\
\hline 1. & $\begin{array}{l}\text { Food services should provide } \\
\text { safe food rather than tasty } \\
\text { food. }\end{array}$ & $\begin{array}{l}22 \\
(3)\end{array}$ & $\begin{array}{l}36 \\
(4)\end{array}$ & $\begin{array}{l}193 \\
(22)\end{array}$ & $\begin{array}{l}327 \\
(38)\end{array}$ & $\begin{array}{l}291 \\
(33)\end{array}$ & $<.001$ \\
\hline 2. & $\begin{array}{l}\text { It is the responsibility of food } \\
\text { handlers to ensure that the } \\
\text { food is safe to be served. }\end{array}$ & $\begin{array}{c}8 \\
(1)\end{array}$ & $\begin{array}{l}10 \\
(1)\end{array}$ & $\begin{array}{l}65 \\
(8)\end{array}$ & $\begin{array}{l}260 \\
(30)\end{array}$ & $\begin{array}{l}526 \\
(61)\end{array}$ & $<.001$ \\
\hline 3. & $\begin{array}{l}\text { Sanitation is an important } \\
\text { responsibility in food handler's } \\
\text { job. }\end{array}$ & $\begin{array}{c}9 \\
(1)\end{array}$ & $\begin{array}{c}4 \\
(1)\end{array}$ & $\begin{array}{l}85 \\
(10)\end{array}$ & $\begin{array}{l}261 \\
(30)\end{array}$ & $\begin{array}{l}510 \\
(59)\end{array}$ & $<.001$ \\
\hline 4. & $\begin{array}{l}\text { The catering management } \\
\text { should educate and train } \\
\text { their employees on personal } \\
\text { hygiene and food safety } \\
\text { regularly. }\end{array}$ & $\begin{array}{l}10 \\
(1)\end{array}$ & $\begin{array}{c}6 \\
(1)\end{array}$ & $\begin{array}{l}49 \\
(6)\end{array}$ & $\begin{array}{l}229 \\
(26)\end{array}$ & $\begin{array}{l}575 \\
(66)\end{array}$ & $<.001$ \\
\hline 5. & $\begin{array}{l}\text { Food handlers should avoid } \\
\text { using their bare hands to rub/ } \\
\text { touch/scratch their face, hair or } \\
\text { any parts of their body in order } \\
\text { to prevent contamination. }\end{array}$ & $\begin{array}{c}6 \\
(1)\end{array}$ & $\begin{array}{c}6 \\
(1)\end{array}$ & $\begin{array}{l}64 \\
(7)\end{array}$ & $\begin{array}{l}214 \\
(25)\end{array}$ & $\begin{array}{l}579 \\
(67)\end{array}$ & $<.001$ \\
\hline 6. & $\begin{array}{l}\text { There should be a proper food } \\
\text { disposal system which would } \\
\text { not attract any animals to the } \\
\text { garbage bin. }\end{array}$ & $\begin{array}{c}9 \\
(1)\end{array}$ & $\begin{array}{l}10 \\
(1)\end{array}$ & $\begin{array}{l}57 \\
(7)\end{array}$ & $\begin{array}{l}328 \\
(27)\end{array}$ & $\begin{array}{l}555 \\
(64)\end{array}$ & $<.001$ \\
\hline 7. & $\begin{array}{l}\text { The catering places should be } \\
\text { kept clean and tidy at all times. }\end{array}$ & $\begin{array}{l}10 \\
(1)\end{array}$ & $\begin{array}{l}7 \\
(1)\end{array}$ & $\begin{array}{l}51 \\
(6)\end{array}$ & $\begin{array}{l}199 \\
(23)\end{array}$ & $\begin{array}{l}602 \\
(69)\end{array}$ & $<.001$ \\
\hline
\end{tabular}




\begin{tabular}{|c|c|c|c|c|c|c|c|}
\hline P. No. & Perception based statement & $\begin{array}{c}\text { SD } \\
\text { N (\%) }\end{array}$ & $\begin{array}{c}\text { D } \\
\text { N (\%) }\end{array}$ & $\begin{array}{c}\mathrm{N} \\
\mathrm{N}(\%)\end{array}$ & $\begin{array}{c}\text { A } \\
\text { N (\%) }\end{array}$ & $\begin{array}{c}\text { SA } \\
\text { N (\%) }\end{array}$ & ${ }^{*} p$ value \\
\hline 8. & $\begin{array}{l}\text { Pesticides and insecticides } \\
\text { should be applied in food } \\
\text { handling and serving areas to } \\
\text { eradicate pests. }\end{array}$ & $\begin{array}{l}66 \\
(8)\end{array}$ & $\begin{array}{c}83 \\
(10)\end{array}$ & $\begin{array}{l}253 \\
(29)\end{array}$ & $\begin{array}{l}211 \\
(24)\end{array}$ & $\begin{array}{l}255 \\
(29)\end{array}$ & $<.001$ \\
\hline 9. & $\begin{array}{l}\text { The garbage bin should be } \\
\text { emptied periodically and kept } \\
\text { closed all the time. }\end{array}$ & $\begin{array}{c}9 \\
(1)\end{array}$ & $\begin{array}{c}6 \\
(1)\end{array}$ & $\begin{array}{l}71 \\
(8)\end{array}$ & $\begin{array}{l}231 \\
(27)\end{array}$ & $\begin{array}{l}552 \\
(64)\end{array}$ & $<.001$ \\
\hline 10. & $\begin{array}{l}\text { Food waste should be collected } \\
\text { in closed containers to avoid } \\
\text { cross contamination. }\end{array}$ & $\begin{array}{c}9 \\
(1)\end{array}$ & $\begin{array}{l}14 \\
(2)\end{array}$ & $\begin{array}{l}78 \\
(9)\end{array}$ & $\begin{array}{l}266 \\
(31)\end{array}$ & $\begin{array}{l}502 \\
(58)\end{array}$ & $<.001$ \\
\hline 11. & $\begin{array}{l}\text { Food waste should be removed } \\
\text { as quickly as possible to avoid } \\
\text { contamination. }\end{array}$ & $\begin{array}{l}10 \\
(1)\end{array}$ & $\begin{array}{c}5 \\
(1)\end{array}$ & $\begin{array}{c}89 \\
(10)\end{array}$ & $\begin{array}{l}269 \\
(31)\end{array}$ & $\begin{array}{l}496 \\
(57)\end{array}$ & $<.001$ \\
\hline 12. & $\begin{array}{l}\text { In order to avoid hand } \\
\text { contamination, the } \\
\text { management could install } \\
\text { elbow or sensor operated taps } \\
\text { for food handling staffs. }\end{array}$ & $\begin{array}{l}10 \\
(1)\end{array}$ & $\begin{array}{l}10 \\
(1)\end{array}$ & $\begin{array}{l}160 \\
(18)\end{array}$ & $\begin{array}{l}256 \\
(30)\end{array}$ & $\begin{array}{l}433 \\
(50)\end{array}$ & $<.001$ \\
\hline
\end{tabular}

${ }^{*}$ Chi square test: $p<.05$ is statistically significant, $\mathrm{SD}=$ Strongly Disagree, $\mathrm{D}=$ Disagree, $\mathrm{N}=$ Neutral, $\mathrm{A}=$ Agree, $\mathrm{SA}=\mathrm{Strongly}$ Agree

\subsection{Overall Total Score Distribution of the Respondents}

Table 5 is summarized with the total median and percentage score distribution of each domain studied. The total knowledge score was found to be moderate
[Mdn. = 11(3), 49\%], whereas the total attitude scores $[\mathrm{Mdn} .=28(3), 87 \%]$, total perception scores $[\mathrm{Mdn} .=54(10), 93 \%]$ and total KAP scores $[\mathrm{Mdn} .=$ 92(11), 90\%] were positive respectively.

Table 5. Total knowledge, attitude, perception and KAP score distribution of respondents

\begin{tabular}{lccccc}
\hline Variables & $\mathbf{N}$ & Median (IQR) & $\begin{array}{c}\text { Poor/ Negative } \\
\mathbf{N}(\%)\end{array}$ & $\begin{array}{c}\text { Moderate/ Neutral } \\
\mathbf{N}(\%)\end{array}$ & $\begin{array}{c}\text { Good/ Positive } \\
\text { N (\%) }\end{array}$ \\
\hline TKS & & $11(3)$ & $146(17)$ & $424(49)$ & $299(34)$ \\
TAS & & $28(3)$ & $30(4)$ & $86(10)$ & $753(87)$ \\
TPS & $869(100 \%)$ & $54(10)$ & $16(2)$ & $49(6)$ & $804(93)$ \\
TKAPS & & $92(11)$ & $15(2)$ & $72(8)$ & $782(90)$ \\
\hline
\end{tabular}

TKS = Total knowledge score, TAS = Total attitude score, TPS = Total perception score, TKAPS = total knowledge, attitude and perception score

\subsection{Correlation between Total Knowledge, Attitude, Perception and KAP Scores $(\mathrm{N}=869)$}

Based on Spearman's rank-order test, the correlation test between total knowledge, total attitude and total perception score was done against total KAP scores which showed significantly strong positive correlations. Table 6 depicts the knowledge score correlation between attitude, perception and total KAP score was found to be $\mathrm{r}_{\mathrm{s}}(896)=.176, p<.001$ and $\mathrm{r}_{\mathrm{s}}(896)=.077, p=.024$, and $r_{s}(869)=.361, p<.001$ respectively, which were positively correlated. The attitude score correlation to knowledge, perception and KAP scores were $r_{s}(896)$ $=.074, p<.001 ; r_{s}(869)=.316, p<.001$ and $r_{s}(869)$ $=.902, p<.001$ respectively that were positively correlated. The perception score correlation to knowledge, attitude and total KAP scores were $\mathrm{r}_{\mathrm{s}}(896)=.077, p=.024 ; \mathrm{r}_{\mathrm{s}}(869)$ $=.316, p<.001$ and $r_{s}(869)=.545, p<.001$ respectively that were positively correlated. The total KAP score correlation to knowledge, attitude and perception scores were $\mathrm{r}_{\mathrm{s}}(896)=.361, p<.001 ; \mathrm{r}_{\mathrm{s}}(869)=.545, p<.001$ and $r_{s}(869)=.902, p<.001$ respectively that were positively correlated. 
Table 6. Correlation between total knowledge, attitude, perception and KAP scores

\begin{tabular}{lcccc}
\hline $\begin{array}{c}\text { Spearman's Rho } \\
\text { correlations }\end{array}$ & TKS & TAS & TPS & TKAPS \\
\hline TKS & 1.000 & $.176^{* *}$ & $.077^{*}$ & $.361^{* *}$ \\
TAS & $.176^{* *}$ & 1.000 & $.316^{* *}$ & $.545^{* *}$ \\
TPS & $.077^{*}$ & $.316^{* *}$ & 1.000 & $.902^{* *}$ \\
TKAPS & $.361^{* *}$ & $.545^{* *}$ & $.902^{* *}$ & 1.000 \\
\hline
\end{tabular}

Spearman's Rho correlation test. ${ }^{* *}$ Correlation is significant at .01 level (2-tailed).

\section{Discussion}

It was important to evaluate the student's knowledge level, as it will influence their perception and attitude. Attitude is evaluated along with knowledge because attitude plays the fundamental role in one's behavior. Based on previous literatures, consumers are more quickly to accept negative statements compared to a positive one without giving a second thought on its importance ${ }^{16}$. Therefore, it is more likely the knowledge level will improve attitude and perceptions and be more proactive in preventing outbreak of food borne diseases.

\subsection{Socio-Demographic Data}

In this study, significant differences in response rate in socio demographic characteristics were found among the study participants. The socio-demographics characteristics of the respondents who contributed to the study the most, were aged between 21-23 years old (56\%), from urban area (78\%), Chinese females (75\%) and non-vegetarians (96\%). Besides that, majority of the respondents were pursuing degree education (77\%), of year one education (39\%), from faculty of pharmacy (24\%). Studies targeting the similar demographic characteristics for age and gender were reported in the United States of America (USA) ${ }^{3}$.

\subsection{Respondents Level of Knowledge in Relation to Food Safety and Hygiene}

In the knowledge section, student's knowledge regarding basicfood safety and hygiene was found to be good. However, extensive /deeper level of knowledge in relation to food safety and hygiene was found to be poor. It was observed that students have an excellent basic level of knowledge regarding food safety and hygiene. This is evident, based on the maximum percentage of correct responses attained by the students on items related to definition of food safety, causes of food borne disease and also symptoms of food borne diseases, (95\%, 94\% and 93\% respectively) followed by minimum percentage of correct responses for question related to common cause of food borne diseases (food poisoning), long term effect of food borne disease, and questions pertaining to storage methods of food. Poor level of knowledge pertaining to common cause of food borne diseases, long term effects of food borne diseases were also found in previous studies conducted by Premarathne et.al. $(2017)^{6}$. Based on the study, factors behind poor extensive knowledge among respondents was due to poor level of awareness among public, as less attention was paid to their eating and preparing methods. In which according to, ByrdBredbenner et.al. (2007) ${ }^{17}$, leads to lesser responsibility in learning and practising safe food handling and preparing methods.

\subsection{Respondents Attitude in Relation to Food Safety and Hygiene}

In attitude section, respondents had acquired high percentage scores, for questions pertaining to personal hygiene, and responsibilities towards maintaining food safety and hygiene. Similar results pertaining personal hygiene and responsibilities towards food safety and hygiene was found in a study conducted by Unklesbay et.al. $(1998)^{18}$. On the other hand, minimum percentage of correct responses regarding statements related to reasons for not washing hands was found in a study conducted by Reeve and Poore, $(2012)^{19}$. It was also supported by another study conducted by Premarathne et.al. $(2017)^{6}$ where food handlers do not wash their hands before preparing a meal, as they considered it to be a waste of time and also due to unawareness of the effects of unclean hands.

\subsection{Students in Relation to Perception of Food Safety and Hygiene}

Overall in perception section, respondents have attained maximum percentage for statements related to personal hygiene of the food handlers, food disposal system, responsibilities of the management towards maintaining a hygienic environment. Based on respondent's observation, majority do agree that food handlers should practice good personal hygiene which contradicts with 
their expectation of poor personal hygiene practice among the food handlers in a study conducted by Thanh et. al. $(2016)^{20}$. However, based on another study, food handlers did not practice personal hygiene, as rub or touch their face with bare hands, which contradict this study, as respondents believe that food handler should not touch/rub their face when they are serving food.

\section{Conclusion}

Majority of respondents were projecting good knowledge, attitude, and perception towards all the domains mainly gender, education and type of diet, as these demographic characteristics show significant value and correlation. This opens up the opportunity to understand how much they know about food safety and hygiene which is in relation to their level of education. Continuous education is necessary to increase the awareness among young adults as in the near future; they will be the ones' directly handling food. Through continuous education, and also campaigns related to food safety and hygiene, it will help them to be more aware of their surrounding and play an important role to help maintain a hygienic and clean environment. The food borne disease outbreak that is prevalent in the country can be subsequently reduced if each and every one of us are responsible enough to take initiatives, rather than pinpointing fingers.

\section{Study Limitation}

The study consists of students from different faculties of a private university, Kedah. Results attained may not be compared with all the students for different ages and academic levels. The study was self-reported, which might have been biased to the respondents as they do not self-reflect their actions while answering. Lack of interest and cooperation among some respondents were noticed during survey. However, all attempts were made to minimize such errors as much as possible through appropriate research design and methodology.

\section{Acknowledgements}

We are grateful to the management of AIMST University, Malaysia for their permission, support and encouragement extended for carrying out this study and the study participants for their time and cooperation for this study.

\section{Supplementary Publications}

The author disclosure that there is a supplementary manuscript submitted for publications elsewhere with the source data and overlapping methods. However, the objective and scope of the manuscript has no overlapping information ${ }^{21}$.

\section{References}

1. Fontannaz F, Miyagishima K. Food hygiene, World Health Organization. 2018. Available from: http://www.who.int/ foodsafety/areas_work/food-hygiene/en/.

2. Byrd-Bredbenner C, Berning J, Martin-Biggers J, Quick V. Food safety in home kitchens: A synthesis of the literature, International Journal of Environmental Research and Public Health. 2013 Sep 2; 10(9): 4060-85. https://doi.org/10.3390/ ijerph10094060. PMid: 24002725, PMCid: PMC3799528.

3. Byrd-Bredbenner C, Abbot JM, Quick V. Food safety knowledge and beliefs of middle school children: Implications for food safety educators, Journal of Food Science Education. 2010 Jan; 9(1): 19-30. https://doi. org/10.1111/j.1541-4329.2009.00088.x.

4. Zimmerman MA. Book Reviews: Health Behavior and Health Education: Theory, Research, and Practice, K. Glanz, FM Lewis, and BK Rimer, Eds., San Francisco, Jossey-Bass; 1990. Health Education Quarterly. 1991 Dec; 18(4): 520-3.

5. Samuel MC, Vugia DJ, Koehler KM, Marcus R, Deneen V, Damaske B, Shiferaw B, Hadler J, Henao OL, Angulo FJ. Consumption of risky foods among adults at high risk for severe foodborne diseases: Room for improved targeted prevention messages, Journal of Food Safety. 2007 May; 27(2): 219-32. https://doi.org/10.1111/j.17454565.2007.00074.x.

6. Premarathne JMKJK, et. al. Microbiological food safety in Malaysia from the academician's perspective, Food Research. 2017; 1(6): 183-202. https://doi.org/10.26656/ fr.2017.6.013.

7. Kaliyaperumal KI. Guideline for conducting a knowledge, attitude and practice (KAP) study, AECS Illumination. 2004 Jan; 4(1): 7-9.

8. Sample Size Calculator by Raosoft, Inc. Raosoft.com. 2018. Available from: http://www.raosoft.com/samplesize.html.

9. Abbot JM, Byrd-Bredbenner C, Schaffner D, Bruhn CM, Blalock L. Comparison of food safety cognitions and selfreported food-handling behaviors with observed food safety behaviors of young adults, European Journal of Clinical Nutrition. 2009 Apr; 63(4): 572. https://doi.org/10.1038/ sj.ejcn.1602961. PMid: 18000516. 
10. Kibret M, Abera B. The sanitary conditions of food service establishments and food safety knowledge and practices of food handlers in Bahir Dar town, Ethiopian Journal of Health Sciences. 2012; 22(1): 27-35. PMid: 22984329, PMCid: PMC3437977.

11. Mullan B, Wong C, Todd J, Davis E, Kothe EJ. Food hygiene knowledge in adolescents and young adults, British Food Journal. 2015 Jan 5; 117(1): 50-61. https:// doi.org/10.1108/BFJ-03-2013-0060.

12. Sani NA, Siow ON. Knowledge, attitudes and practices of food handlers on food safety in food service operations at the Universiti Kebangsaan Malaysia, Food Control. 2014 Mar 1; 37: 210-7. https://doi.org/10.1016/j. foodcont.2013.09.036.

13. Zulkifly MI, Salleh MM, Hanafiah MM, Jamaluddin MR. Assessing Knowledge, Attitude and Practice (KAP) on food safety among food handlers in Universiti Teknologi Mara (UiTM), Shah Alam, Hospitality and Tourism, Chapter: 107. 2013: 567-72.

14. Mashuba D. Knowledge and practices of food service staff regarding food safety and food hygiene in the Capricorn District Hospitals in the Limpopo Province, South Africa. Ulspace.ul.ac.za. Available from: http://ulspace.ul.ac.za/ handle/10386/1487.

15. Henson RK. Understanding internal consistency reliability estimates: A conceptual primer on coefficient alpha, Measurement and Evaluation in Counseling and Development. 2001 Oct 1; 34(3): 177.

16. McCluskey JJ, Swinnen JF. Political economy of the media and consumer perceptions of biotechnology,
American Journal of Agricultural Economics. 2004 Dec 1; 86(5): 1230-7. https://doi.org/10.1111/j.00029092.2004.00670.x.

17. Byrd-Bredbenner C, Maurer J, Wheatley V, Schaffner D, Bruhn C, Blalock L. Food safety self-reported behaviors and cognitions of young adults: Results of a national study, Journal of Food Protection. 2007 Aug; 70(8): 1917-26. https://doi.org/10.4315/0362-028X-70.8.1917. PMid:17803150.

18. Unklesbay NA, Sneed J, Toma R. College students' attitudes, practices, and knowledge of food safety, Journal of Food Protection. 1998 Sep; 61(9): 1175-80. https://doi. org/10.4315/0362-028X-61.9.1175. PMid: 9766071.

19. Stone KM, Karem KL, Sternberg MR, McQuillan GM, Poon AD, Unger ER, Reeves WC. Seroprevalence of human papillomavirus type 16 infection in the United States, The Journal of Infectious Diseases. 2002 Nov 15; 186(10): 1396-402. https://doi.org/10.1086/344354. PMid: 12404154.

20. Samapundo S, Thanh TC, Xhaferi R, Devlieghere F. Food safety knowledge, attitudes and practices of street food vendors and consumers in Ho Chi Minh city, Vietnam, Food Control. 2016 Dec 1; 70: 79-89. https://doi. org/10.1016/j.foodcont.2016.05.037.

21. Ali AN, Angelene PS. Self-reported association and determinants of KAP on food safety and hygiene among private University Students in Kedah State, Malaysia, MOJ Bioequiv Availab. 2018; 5(5): 256-62. 